\title{
WAWASAN NUSANTARA: SEBAGAI SATU KESATUAN, POLOTIK, EKONOMI, SOSIAL, BUDAYA DAN HANKAM
}

Oleh:

\author{
Anita Laki Mbatu \\ 2171B0004 \\ S-I Administrasi Rumah Sakit \\ IIK STRADA Inodesia \\ Anitambatu12@gmail.com
}

\begin{abstract}
Abstrak
Wawasan nusantara adalah cara pandang bangsa Indonesia terhadap rakyat, bangsa, dan wilayah Negara Kesatuan Republik Indonesia (NKRI) yang meliputi darat, laut, dan udara di atasnya sebagai satu kesatuan politik, ekonomi, sosial, budaya, dan pertahanan keamanan. Wawasan nusantara berasal dari kata 'wawasan' dan 'nusantara'. Wawasan berasal dari kata 'wawas' (bahasa Jawa) yang berarti pandangan, tinjauan atau penglihatan indrawi. Selanjutnya, muncul kata 'mawas', yang berarti memandang, meninjau atau melihat.Seperti diketahui, negara Indonesia merupakan negara multikultural. Indonesia memiliki suku, ras maupun agama yang sangat beragam.Itulah mengapa, penting memahami banyaknya perbedaan tersebut melalui wawasan nusantara. sebagai warga negara yang baik, hendaknya memiliki wawasan nusantara sebagai bentuk perwujudan rasa nasionalisme.

Pemahaman wawasan nusantara juga akan meningkatkan rasa bangga atas bangsa karena sesungguhnya Indonesia dikaruniai dengan keberagaman, tetapi tetap bisa bersatu.Sebagai warga negara yang baik, penting untuk mengenali makna wawasan nusantara bagi bangsa Indonesia.Makna wawasan nusantara bagi bangsa Indonesia mengandung arti cara pandang dan pengetahuan. Makna wawasan nusantara bagi bangsa Indonesia dikaitkan dengan dasar ideologi dan konstitusional.
\end{abstract}

Kata kunci: wawasan nusantara: sebagai satu kesatuan, polotik, ekonomi, sosial, budaya dan hanka

A. Pendahuluan

Wawasan nusantara adalah cara pandang atau cara melihat kesatuan kepulauan yang terletak diantara (Asia dan Australia) juga dua samudera (Hindia dan Pasifik).

Berdasarkan TAP MPR tahun 1993 dan 1998 tentang GBHN, wawasan nusantara adalah cara pandang dan sikap bangsa Indonesia, tentang jati diri dan lingkungan yang mengutamakan persatuan dan kesatuan bangsa, serta kesatuan wilayah demi tercapainya tujuan nasional.

Perwujudan Wawasan Nusantara sebagai kesatuan dalam mencapai tujuan Pembangunan Nasional mencakup beberapa aspek kesatuan, seperti kesatuan politik, ekonomi, sosial budaya, dan pertahanan keamanan(hankam). 
Indonesia adalah negara yang memiliki berbagai keragaman di dalamnya. Misalnya dlihat dari suku bangsanya, negara ini terdiri dari berbagai suku seperti Jawa Sunda, Dayak, Bugis, dan sebagainya. Dari setiap suku bangsa memiliki beraneka budaya yang memperkaya corak budaya asli Indonesia. Semua keanekaragaman tersebut memerlukan persatuan. Dengan persatuan, maka semua yang tampak berbeda itu dapat bersatu sebagai kebulatan yang utuh. Dan, bersatu bangsa didorong dari kemauan secara sadar dan penuh tanggung jawab dalam mencapai kehidupan bangsa yang bebas di suatu wadah negara merdeka, berdaulat, adil, dan makmur. Menurut laman Kementrian Keuangan, persatuan dan kesatuan adalah prasyarat utama jika ingin melakukan pembangunan di suatu negara. Dalam kemajemukan masyarakat diperlukan kemampuan menjaga, mengembangkan, dan mewujudkan persatuan dan kesatuan di dalam kehidupan masyarakat.

\section{B. Pembahasan}

1. Makna wawasan nusantara sebagai kesatuan politik ekonomi

Sebagai kesatuan politik, wawasan nusantara mengandung makna:

a. Kebulatan wilayah nasional beserta kekayaannya merupakan satu kesatuan wilayah, wadah, ruang hidup, dan kesatuan seluruh bangsa serta menjadi modal dan milik bersama rakyat Indonesia.

b. Bangsa Indonesia terdiri dari berbagai suku dan berbicara agama dan kepercayaan terhadap Tuhan YME, harus merupakan satu kesatuan bangsa yang bulat dalam arti yang seluas-luasnya.

c. Secara psikologis, bangsa Indonesia harus merasa satu rasa senasib sepenanggungan, sebangsa setanah air dan punya satu tekad dalam mencapai cita-cita bangsa.

d. Pancasila sebagai satu-satunya falsafah, ideologi negara yang senantiasa membimbing dan mengarahkan bangsa Indonesia dalam mencapai tujuannya.

Sebagai kesatuan ekonomi, wawasan nusantara mengandung makna:

a. Kekayaan nusantara baik potensial maupun efektif adalah modal dan milik bangsa Indonesia. Kekayaan itu harus dikelola untuk keperluan sehari-hari dan merata di semua wilayah.

b. Tingkat perkembangan ekonomi harus serasi dan seimbang di seluruh daerah, tanpa meninggalkan ciri khas yang dimiliki oleh daerah dalam pengembangan kehidupan ekonominya.

c. Kehidupan perekonomian di seluruh wilayah nusantara merupakan satu kesatuan ekonomi yang diselenggrakan sebagai usaha bersama atas asas kekeluargaan dan ditunjukkan bagi kemakmuran semua rakyat.

2. Makna wawasan nusantara sebagai kesatuan social budaya dan pertahanan keamanan Sebagai satu kesatuan sosial budaya, wawasan nusantara mengandung makna: 
a. Masyarakat Indonesia sebagai satu perikehidupan bangsa harus merupakan kehidupan yang serasi dengan tingkat kemajuan masyarakat yang sama, merata dan seimbang serta adanya keselarasan yang sesuai dengan tingkat kemajuan bangsa.

b. Budaya Indonesia pada dasarnya adalah satu kesatuan dalam keberagaman. Inilah yang menjadi modal dasar pembangunan dan sekaligus jati diri bangsa.

Sebagai satu kesatuan pertahanan keamanan, wawasan nusantara mengandung makna:

a. Segala ancaman terhadap satu pulau atau daerah pada dasarnya adalah ancaman bagi bangsa Indonesia secara keseluruhan.

b. Setiap warga negara memiliki hak dan kewajiban yang sama dalam membela negara dan bangsa.

Fungsi Wawasan Nusantara :

- Fungsi Wawasan Nusantara secara Umum

Fungsi wawasan nusantara secara umum ialah berperan sebagai pedoman, motivasi, dorongan, dan rambu-rambu untuk memastikan semua kebijaksanaan, ketentuan, tindakan, serta perbuatan dalam penyelenggaraan negara, baik pusat maupun daerah.

Wawasan nusantara juga berfungsi untuk membentuk dan membina persatuan kesatuan bangsa dan negara Indonesia serta merupakan ajaran dasar nasional yang melandasi kebijakan serta langkah pembagunan nasional di Indonesia.

- Fungsi Wawasan Nusantara Menurut Para Ahli

a) Fungsi wawasan nusantara sebagai konsepsi ketahanan nasional yaitu sebagai konsep dalam pembangunan, pertahanan keamanan serta kewilahayan.

b) Fungsi wawasan nusantara sebagai pembangunan nasional yaitu meliputi kesatuan politik, sosial dan ekonomi, sosial dan politik, kesatuan pertahanan serta keamanan.

c) Fungsi wawasan nusantara sebagai pertahanan dan keamanan yaitu pandangan geopolitik Indonesia sebagai satu kesatuan pada seluruh wilayah serta seluruh kekuatan negara.

d) Fungsi wawasan nusantara sebagai wawasan kewilayahan yaitu pembatasan negara untuk menghindari adanya sengketa antarnegara tetangga.

Tujuan Wawasan Nusantara :

- Tujuan Wawasan Nusantara Nasional

Tujuan nasional dapat dilihat dalam pembukaan Undang-Undang Dasar 1945. Dalam UUD 1945 tersebut dijelaskan tujuan kemerdekaan Indonesia ialah untuk melindungi segenap bangsa Indonesia dan seluruh tumpah darah Indonesia, serta mewujudkan kesejahteraan umum, mencerdaskan kehidupan bangsa, dan ikut melaksanakan ketertiban dunia yang berdasarkan kemerdekaan perdamaian abadi dan keadilan sosial.

- Tujuan Wawasan Nusantara Keluar 
Tujuan wawasan nusantara Indonesia keluar adalah menjamin kepentingan nasional dalam era globalisasi yang makin mendunia maupun kehidupan dalam negeri.

Lalu, turut serta melaksanakan ketertiban dunia berdasarkan kemerdekaan, perdamaian abadi, keadilan sosial, serta kerja sama dan sikap saling hormat menghormati.

- Tujuan Wawasan Nusantara ke Dalam

Tujuan wawasan nusantara ke dalam adalah menjamin persatuan dan kesatuan di segenap aspek kehidupan nasional, baik aspek alamiah maupun aspek sosial.

Bangsa Indonesia harus meningkatkan kepekaan dan berusaha mencegah dan mengatasi sedini mungkin faktor-faktor penyebab timbulnya disintregasi bangsa dan terus-menerus mengupayakan dan terjaganya persatuan dan kesatuan dalam kebhinnekaan.

\section{Kesimpulan}

Dari uraian diatas maka dapat disimpulkan bahwa Wawasan nusantara memiliki cara pandang dan sikap bangsa mengenai diri dan lingkungan yang serba beragam dan bernilai strategis dengan mengutamakan persatuan dan kesatuan bangsa serta wilayah dalam menyelenggarakan kehidupan bermasyarakat, berbangsa, dan bernegara dengan tujuan mencapai tujuan nasional." Wawasan nusantara dibagi menjadi dua tujuan utama, diantaranya: wawasan nusantara juga akan meningkatkan rasa bangga atas bangsa karena sesungguhnya Indonesia dikaruniai dengan keberagaman, tetapi tetap bisa bersatu.Sebagai warga negara yang baik, penting untuk mengenali makna wawasan nusantara bagi bangsa Indonesia.Makna wawasan nusantara bagi bangsa Indonesia mengandung arti cara pandang dan pengetahuan. Makna wawasan nusantara bagi bangsa Indonesia dikaitkan dengan dasar ideologi dan konstitusional.

Tujuan dari wawasan nusantara adalah mewujudkan naisionalisme yang tinggal di segala bidang dari rakyat Indonesia yang lebih mengutamakan kepentingan naisonal dari pada kepentingan perorangan dari pada kelompok, golongan, suku bangsa atau daerah. 


\section{DAFTAR PUSTAKA}

Kaelan dan zubaidi, ahmad, 2007, “Pendidikan Kewarganegaraan Untuk Perguruan Tinggi ”, Yogyakarata : paradigm.

Ginarja, Agustian, 2008, “Mencintai Banggsa Dan Negara “, Bogor, PT. Sarana Komunikasi Utama.

Srijanti, dkk, 2009 , “Pendidikan Kewarganegaraan Untuk Mahasiswa “, Jakarta: graha. 